\title{
Thematic Analysis of Op. 37 3. Piano Concerto by L. v. Beethoven: The Third Movement Consisting of the First Movement
}

\author{
Assoc. Prof. Fahrettin Eren Yahşi \\ State Conservatory, Anadolu University, PO Box 26050, Eskişehir, Turkey
}

\begin{abstract}
In this study, unique personality of Beethoven and its reflection on his music are discussed based on Op. 373. Piano Concerto. Concerto was analyzed in line with his innovative approaches, which are more evident especially in his second period works covering the years 1801-1814; therefore, thematic mastery, which is clearly predictable, was analyzed. In the light of these, it is aimed that this study will be a guide for musicians who want to learn about the concerto and improve themselves in this field.
\end{abstract}

Keywords: L. v. Beethoven, Piano, Concerto, Theme, Analysis

DOI: $10.7176 / \mathrm{ADS} / 95-02$

Publication date:September $30^{\text {th }} 2021$

\section{Introduction}

Ludwig van Beethoven was one of the composers with the most extraordinary personality in music history; this characteristic of him was the most distinctive property of his music as well as of his every part of life. He wanted to move on reflecting his inner world on his music by protesting the music composing traditions of the time in a rebellious way and this approach brought him to a different position of his contemporaries. It is for sure that the brilliance of the other composers of the period such as F. J. Haydn, W.A. Mozart is unquestionable; however, what separates him from the others is that he described himself as an artist and therefore, he thought that he was above the aristocracy. While the other composers were trying to enter into the service of aristocracy, Beethoven easily got into the aristocracy and made himself accepted among them as an artist (Schonberg, 2013, p.104).

The first works of Beethoven are seen as the continuation of the musical and formal approaches of the period he lived. He enlarged the forms of the period and gave new points of views to them. However, although it is possible to see the properties of the classical period in his works, the traces of the influence he would transmit in the future while creating his music are also clearly observed. His works in the second which covers the years 1801-1814 make his genius more evident (Schindler, 1996, p.88). This period which is thought to start with "Eroica" symphony, is the period when Classical Period sonata form was evolved through his point of view. Presenting his individualism confidently resulted in going out of the well-known properties of sonata form. Beethoven succeeded in adapting this form to his musical ideas by flexing it (Schonberg, 2013, p.114). His genius in this form is to be able to construct a whole musical structure through only a few notes. Op. 37 3. Piano Concerto was composed in this period when he started to master on sonata form and present his musical expressions in a clear way.

\section{Op. 37 3. Piano Concerto (1803-1804)}

It is seen as a first impression that the form of the concerto reflects the characteristics of the period. Sonata allegro form of the first movement and being traditional of the form of Rondo which is the third part are extremely clear. Although the form of the concerto conforms the traditional rules, musical structure includes totally new approaches for that period. The concerto was composed in a way that focused only on reflecting the emotions away from being ornamented and viscous both in the processing and the development movements. In other words, the composer did not try to meet the expectation of the aristocracy through his work and he wanted to express his inner world through music. Therefore, this situation that can clearly be observed in the second period works of Beethoven was reflected on this concerto. It would not be wrong to say especially regarding the introduction of the second movement that it is one of the first ideas of the romantic period although it can be evaluated within the traditions of that period. This idea is musical expression or playing with an expression. Beethoven wanted to express the music in his mind and his heart through a simple melody, and it was accompanied by a quite intense harmonic structure. 
Largo. (M.M. $A=69$; Czerny = 66.) senza sordino (1) e pianissimo.
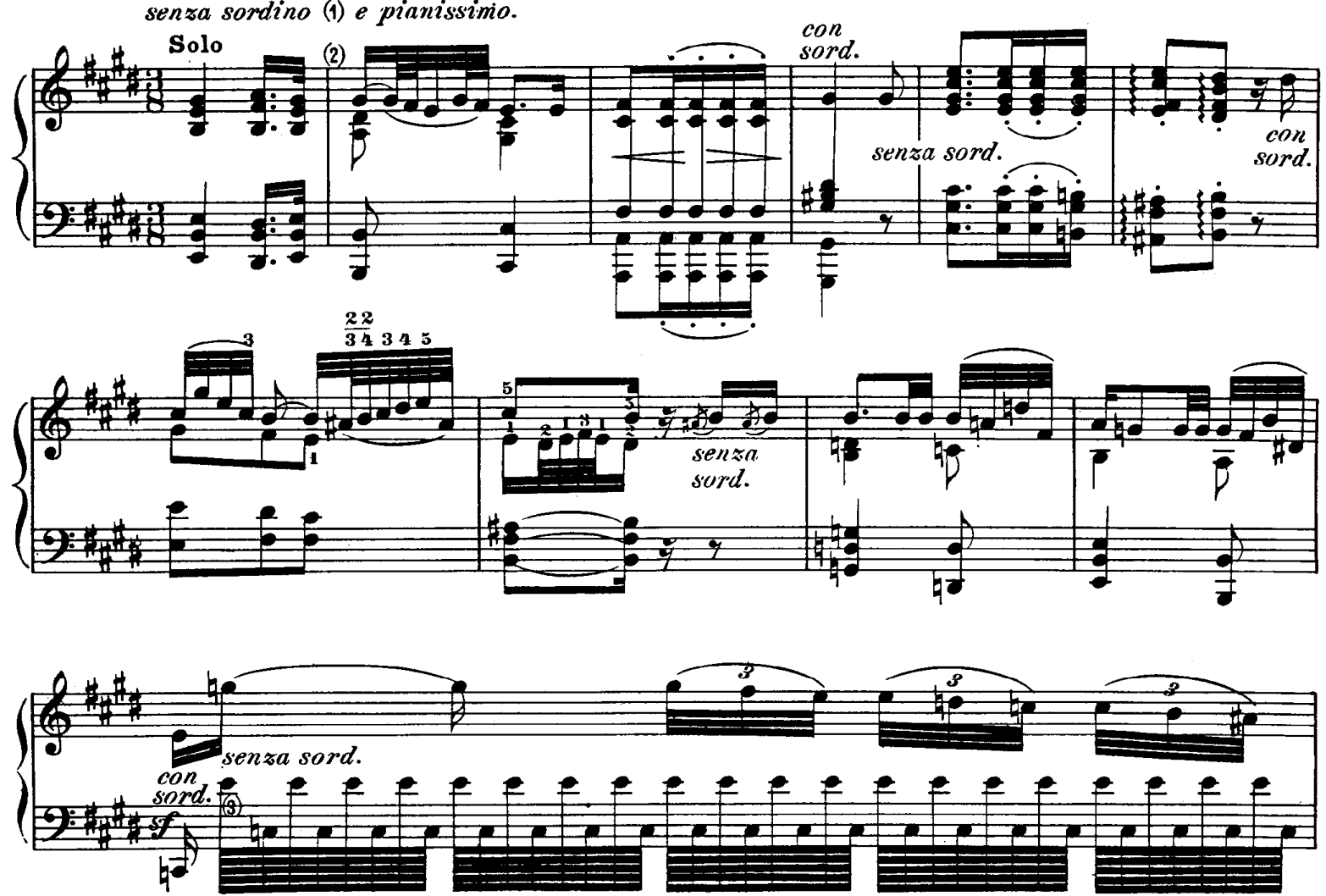

Figure 1: Op. 37 3. Piano Concerto $2^{\text {nd }}$ Movement, $1^{\text {st }}-11^{\text {th }}$ Measure

Additionally, cadences in the third movement bear the tones of classical period as a style; however, they can be interpreted as the first steps of romantic period approach since they include virtuosity. These kinds of cadences in the classical period were left to the performer to improvise. The cadences in this concerto were written by Beethoven and he did not provide a chance for the performer to improvise. Considering the beat of the third movement, technical challenge of the written cadences can be seen. It is not correct to compare these cadences to the works of subsequent composers of Beethoven; yet, when the concertos written in that period by other composers are evaluated, virtuosity in Beethoven's concerto becomes more evident.
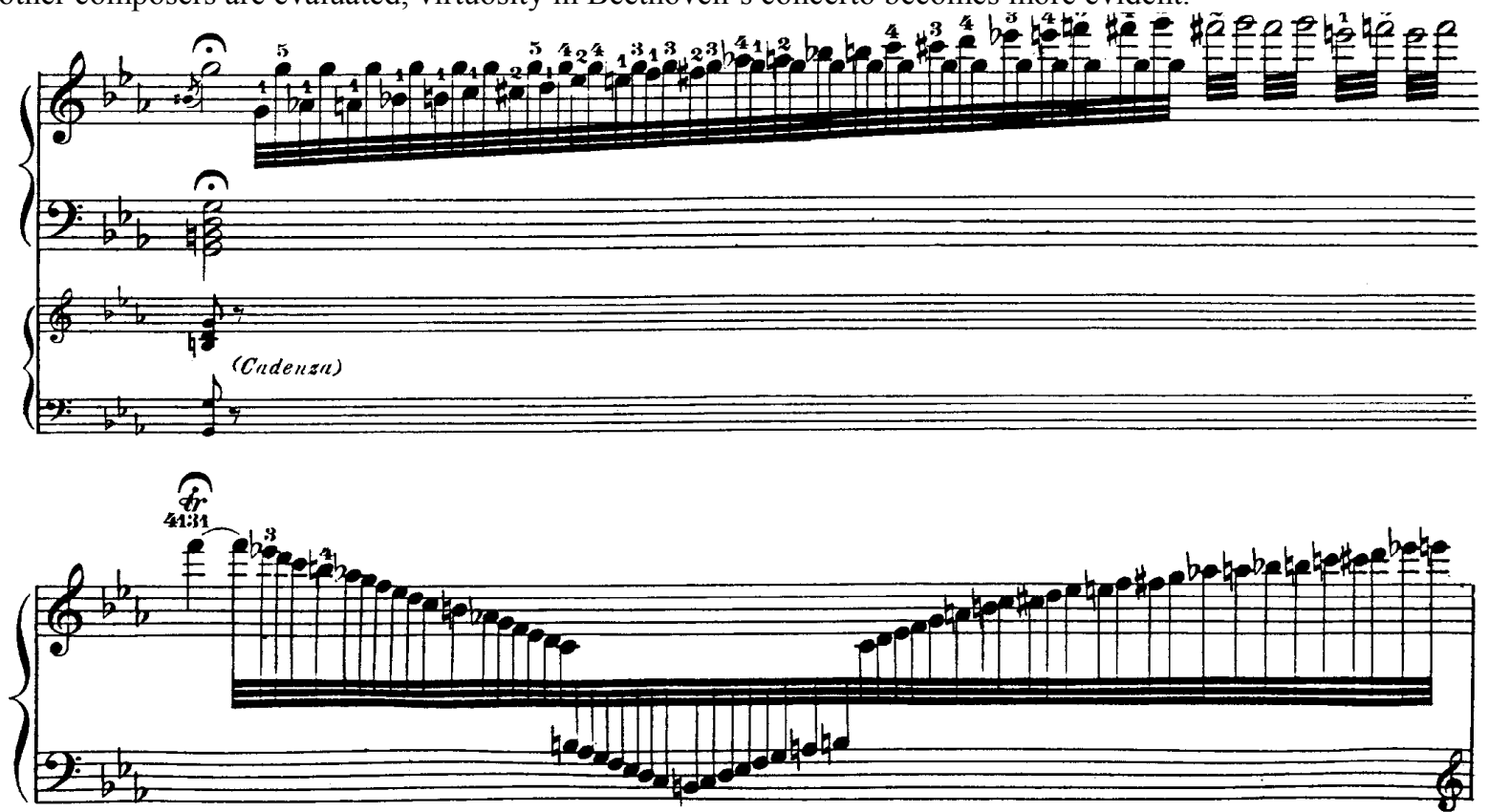

Figure 2: Op. 37 3. Piano Concerto $3^{\text {rd }}$ Movement, 154 th Measure (A theme $2^{\text {nd }}$ Cadence) 
In line with all these, the concerto represents classical period in terms of form and style, but it is ahead of its time through its thematic ideas and virtuoso approaches.

\section{The Third Movement Consisting of the First Movement}

First, it is necessary to analyze the main theme of the first movement. In the continuation of the theme, it is seen that the pattern that composes it is based on three notes.
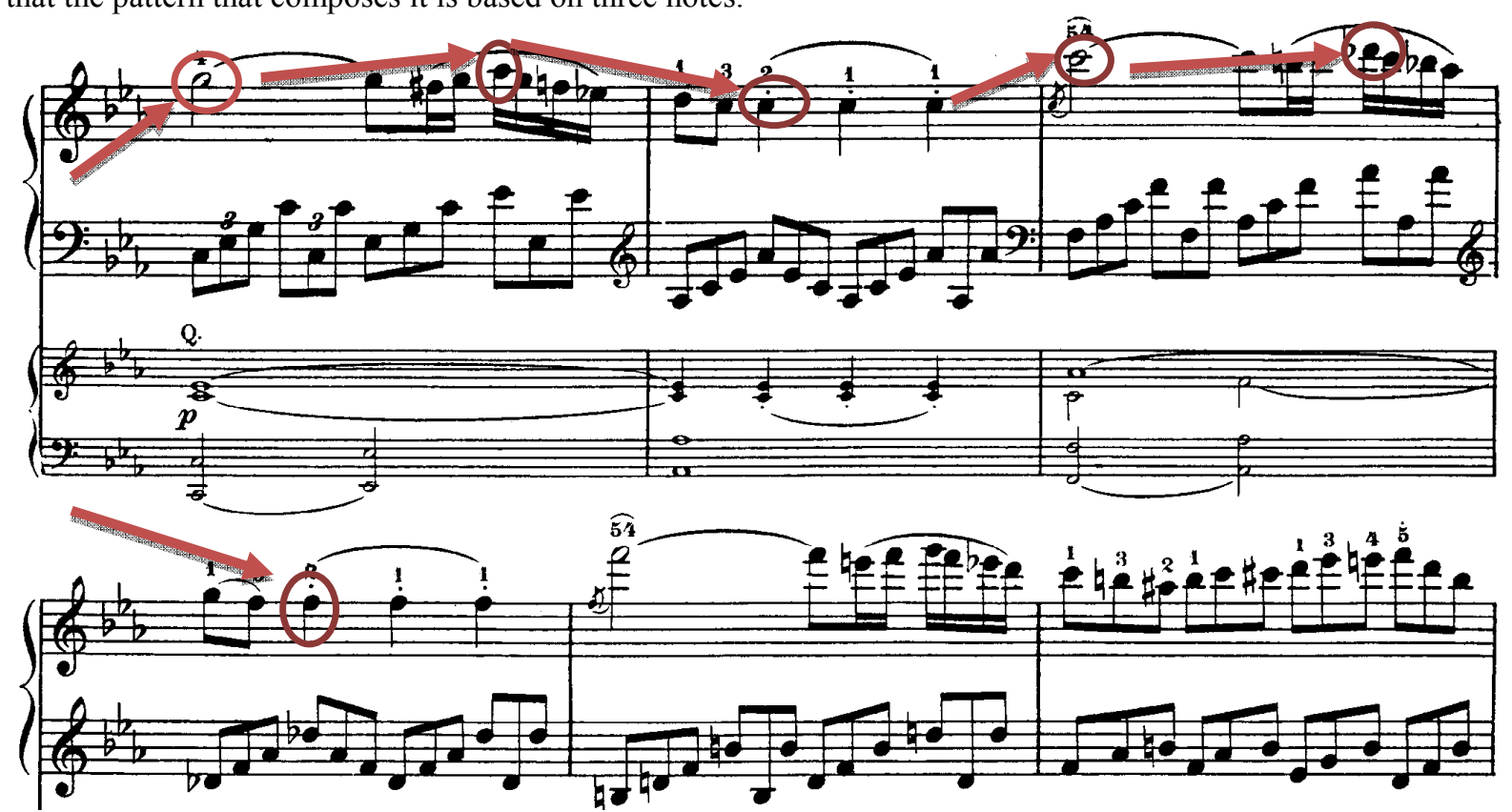

Figure 3: Op. 37 3. Piano Concerto $1^{\text {st }}$ Movement, 122-126 $6^{\text {th }}$ Measures

The frame which consists of A, C and G trio composes the melody through secondary notes. There is a small ascending interval between the first two notes and there is a large descending interval in the continuation. This structure appears in two different ways in the third movement. The first one is the theme A which is the first theme of the movement.

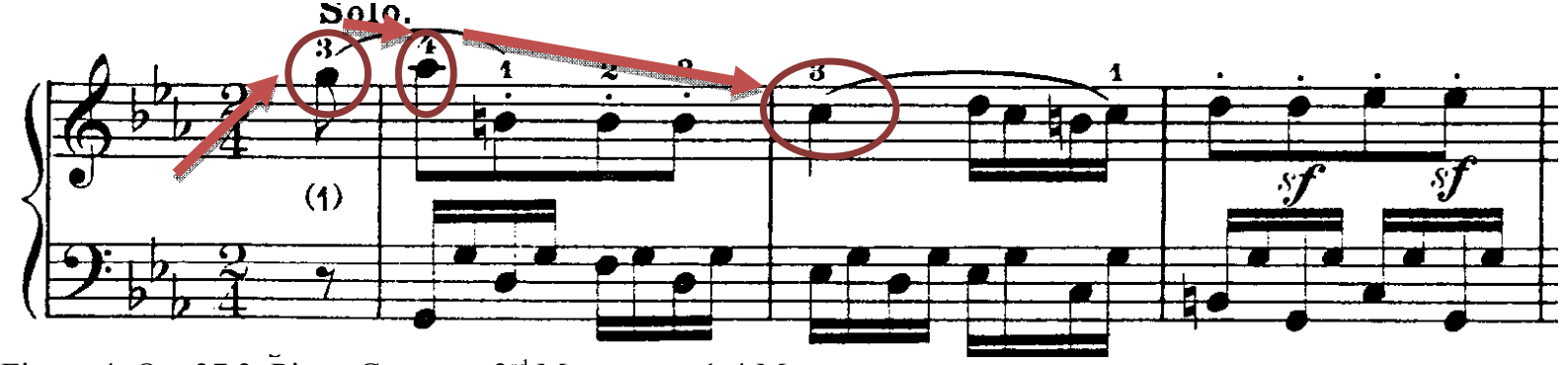

Figure 4: Op. 37 3. Piano Concerto $3^{\text {rd }}$ Movement, 1-4 Measures

As in the theme in the first movement, there is not a descending movement in the last note of the frame. The only thing that does not change here is the frame itself and the direction of the notes that compose it. Beethoven created a new melody with the same frame by changing the secondary notes. The second one is the $\mathrm{C}$ theme of the third movement which moves in the opposite direction of the frame consisting of three notes and the pattern in the first movement created by it. 


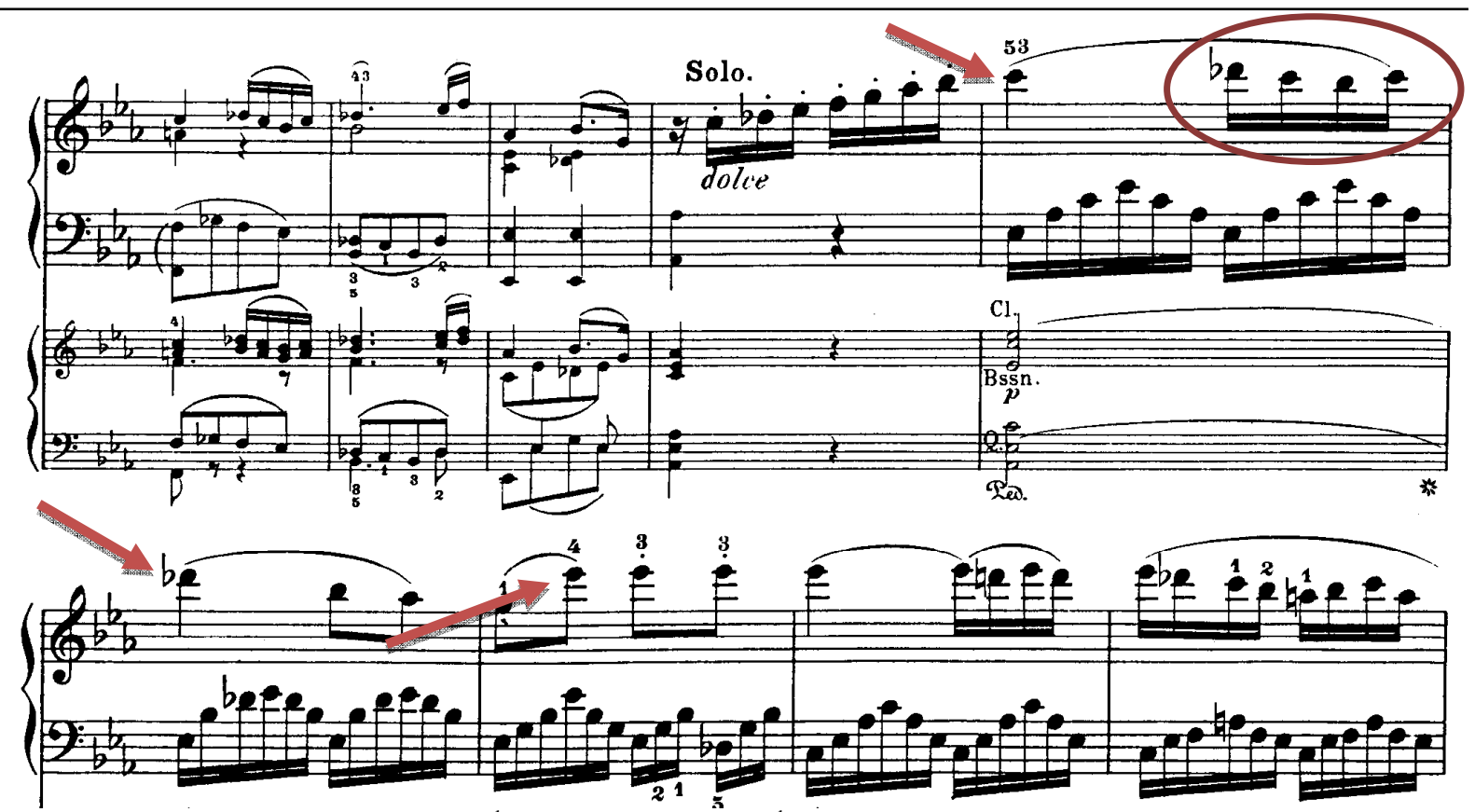

Figure 5: Op. 37 3. Piano Concerto $3^{\text {rd }}$ Movement, $189-196^{\text {th }}$ Measures

The frame in this theme was thought in the opposite direction. In other words, it can be thought as an upside-down reflection of the first movement. Here, the direction of the frame appears in an ascending movement. The ascending movement in the last note is the reverse reflection of the movement in the first part. Additionally, secondary notes were written in the reverse direction of the pattern in the first theme. In this way, $\mathrm{A}$ and $\mathrm{C}$ themes in the third movement consist of the first thematic pattern in the first movement. The pattern which is in the developing part of the first movement and is used as a bridge between the themes composes

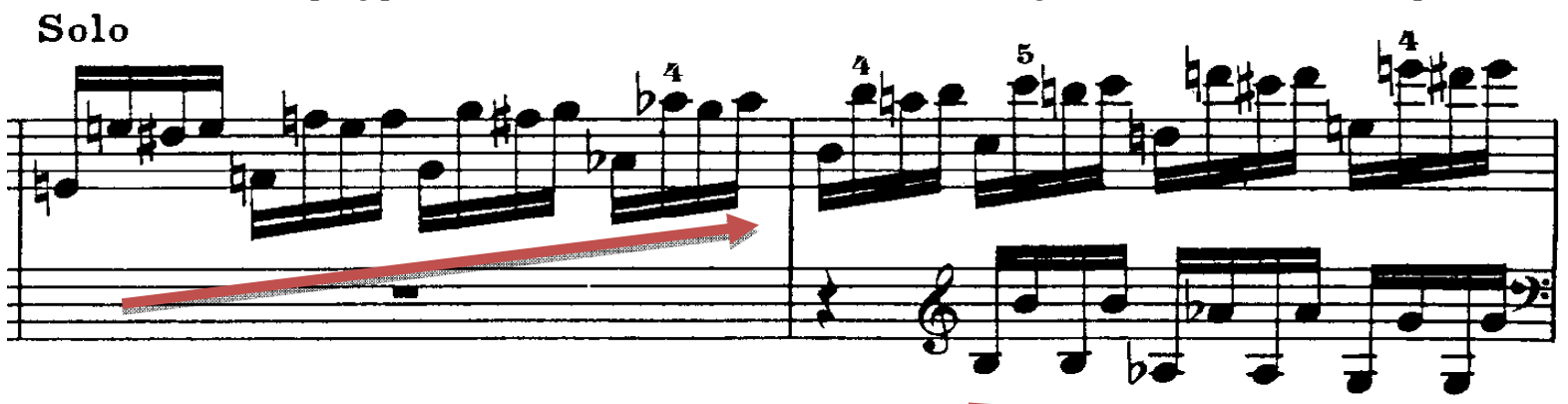

Figure 6: Op. 37 3. Piano Concerto $1^{\text {st }}$ Movement 269-270 $0^{\text {th }}$ Measures 
B1 pattern which is the second part of B theme in the third movement.
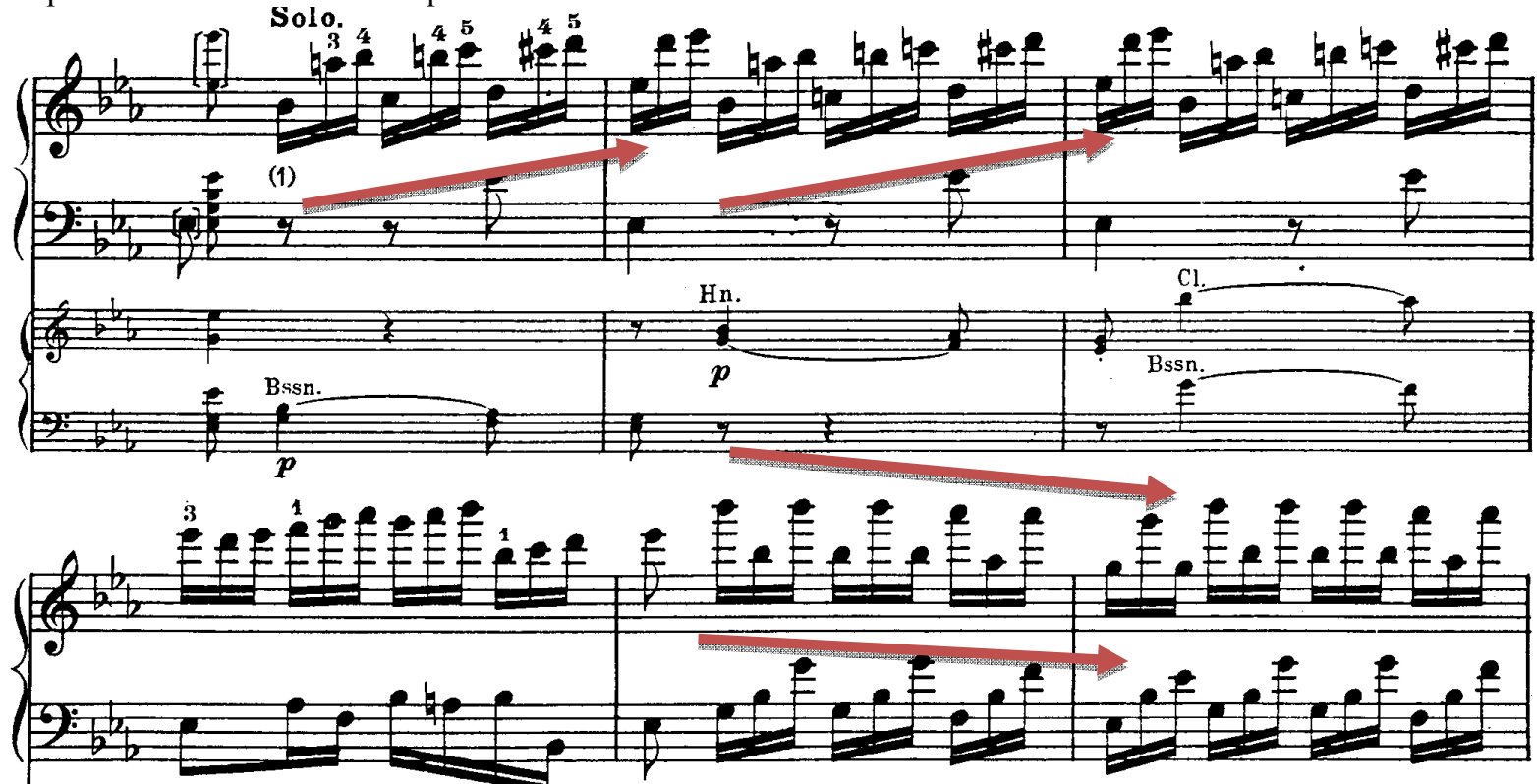

Figure 7: Op. 37 3. Piano Concerto $3^{\text {rd }}$ Movement $85-90^{\text {th }}$ Measures

The similarity here is the movement with a common direction. The movement direction and the structure of the themes and patterns that are heard differently in the second movement are almost the same. The part of the pattern on the left hand in the first movement is used for both hands in the second part of the theme in the third movement and a common melody was created. Another pattern that composes the third movement is the second theme in the developing part of the first movement.

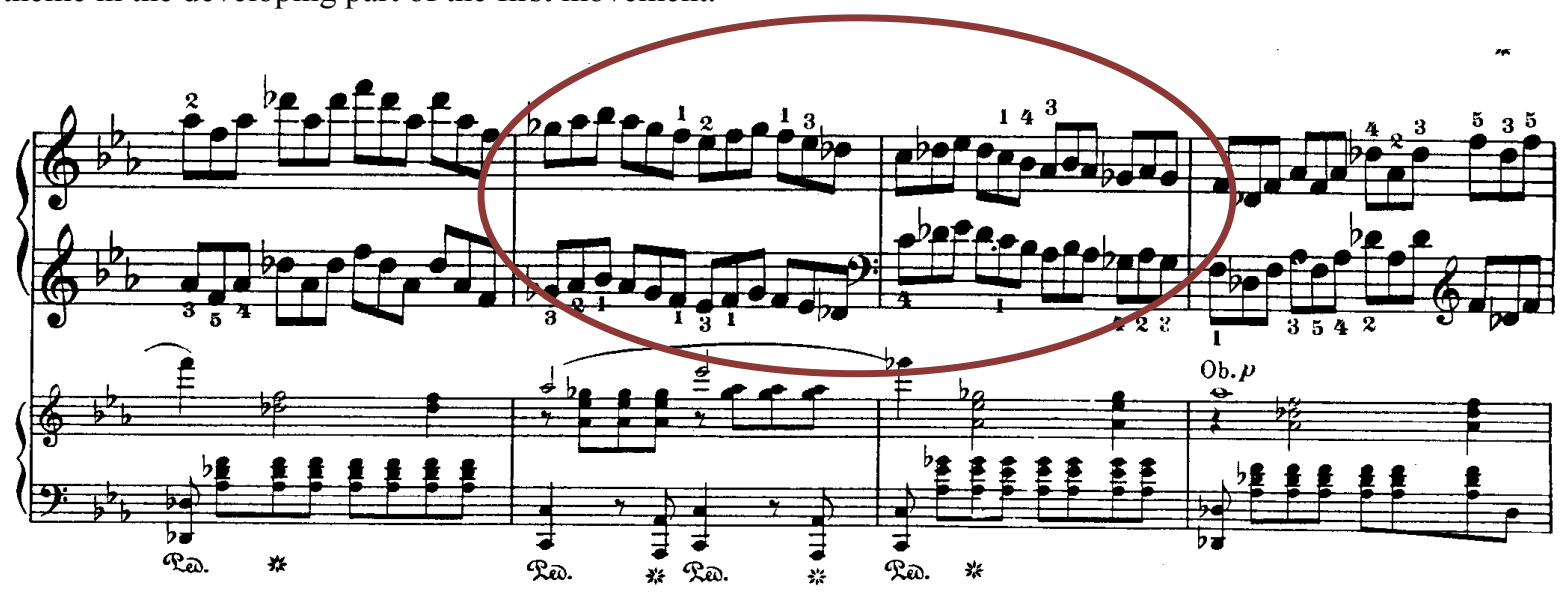

Figure 8: Op. 37 3. Piano Concerto $1^{\text {st }}$ Movement 284-287 $7^{\text {th }}$ Measures 
The part above composes the end of the B thente in the third movement.

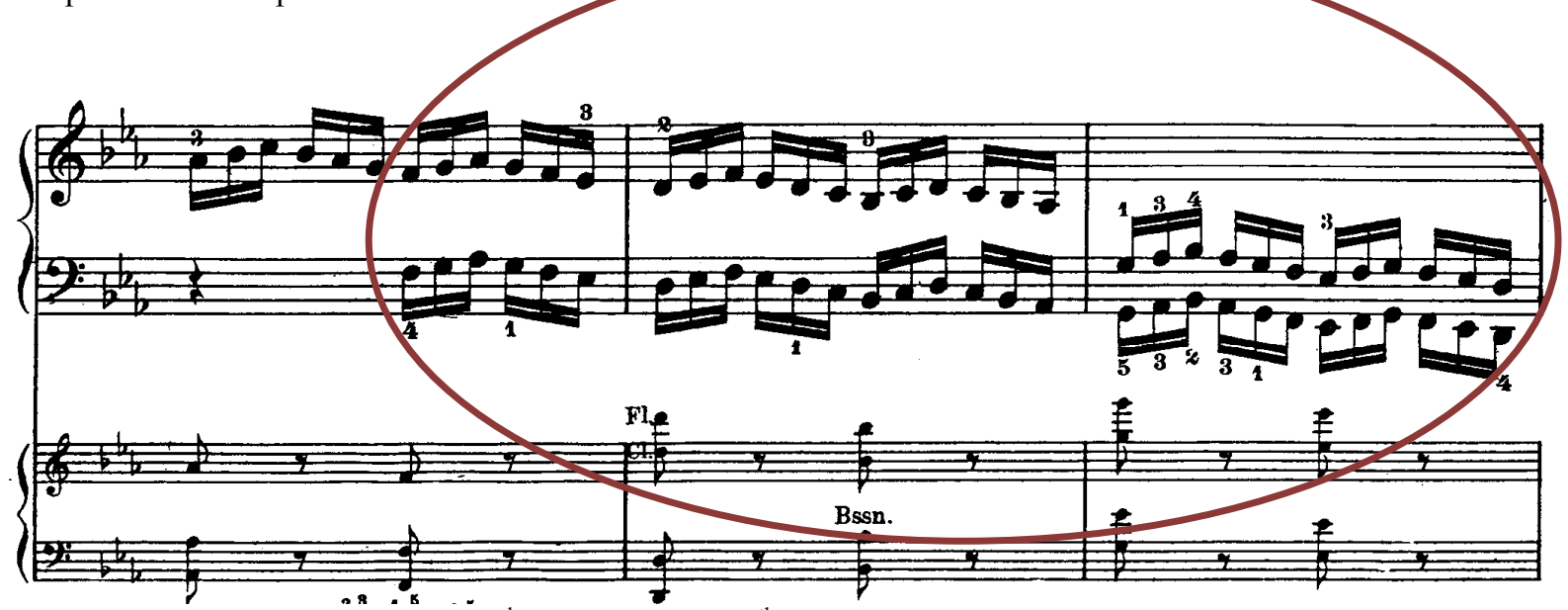

Figure 9: Op. 37 3. Piano Concert $3^{\text {rd }}$ Movement $94-96^{\text {th }}$ Measures

That means the bridge and the second theme in the developing part of the first movement create almost the entire B1 theme in the third movement. Furthermore, the transition patterns in the first movement are used in a similar way in the third movement. This similarity can be observed especially in the transitions before the coda and the closure patterns of the coda in the third movement.

When the bridges in the A theme in the first movement are analyzed,

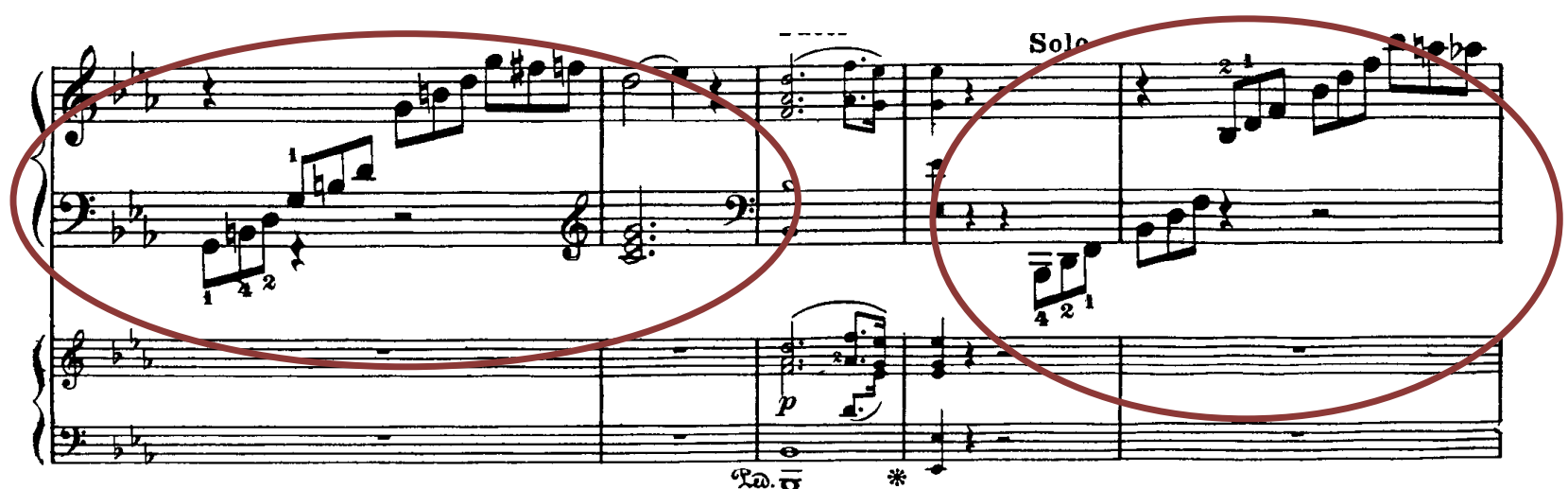

Figure 10: Op. 37 3. Piano Concerto $1^{\text {st }}$ Movement $133^{\text {rd }}-137^{\text {th }}$ Measures

It is seen that the variations of these patterns are used at the point where A theme is returned and before the coda for a few times in the third movement.

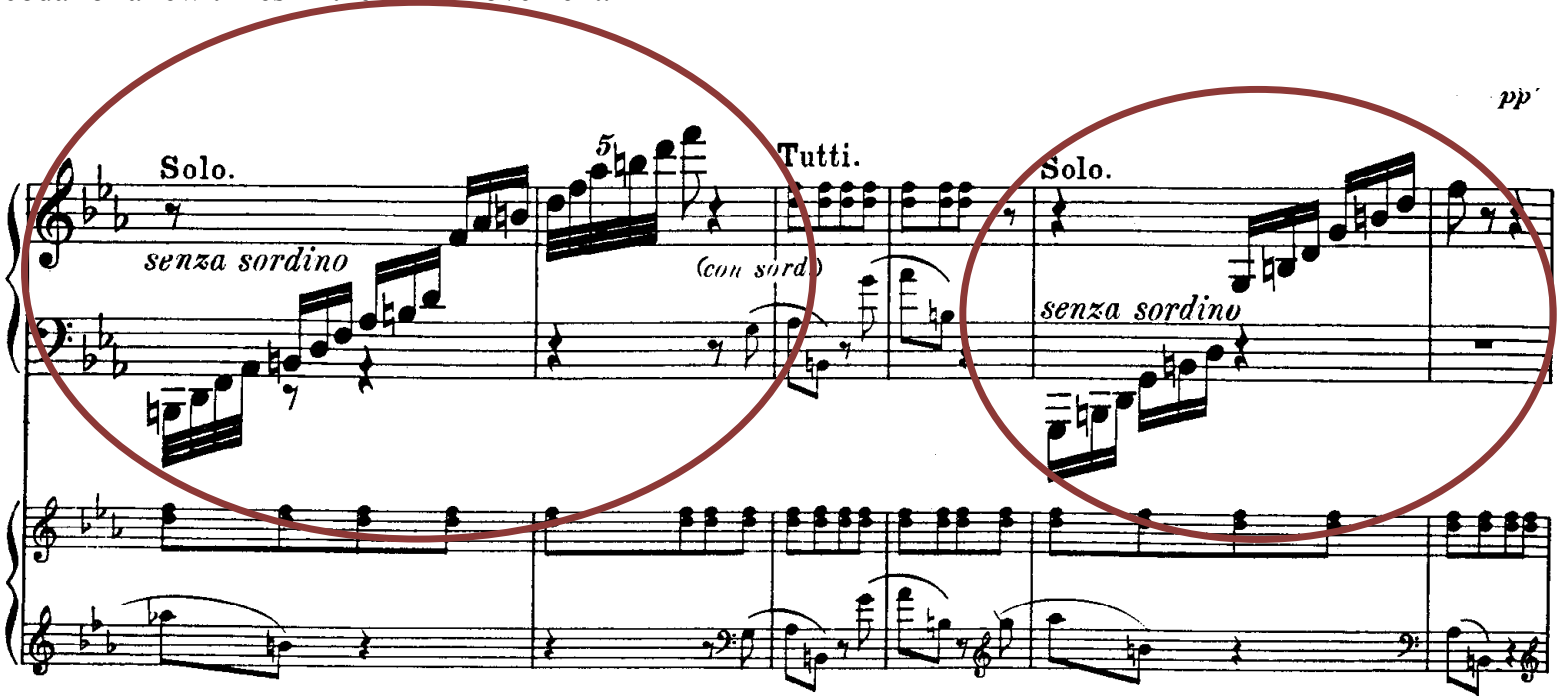

Figure 11: Op. 37 3. Piano Concerto $3^{\text {rd }}$ Movement 284-289 ${ }^{\text {th }}$ Measure (Before the A Theme) 


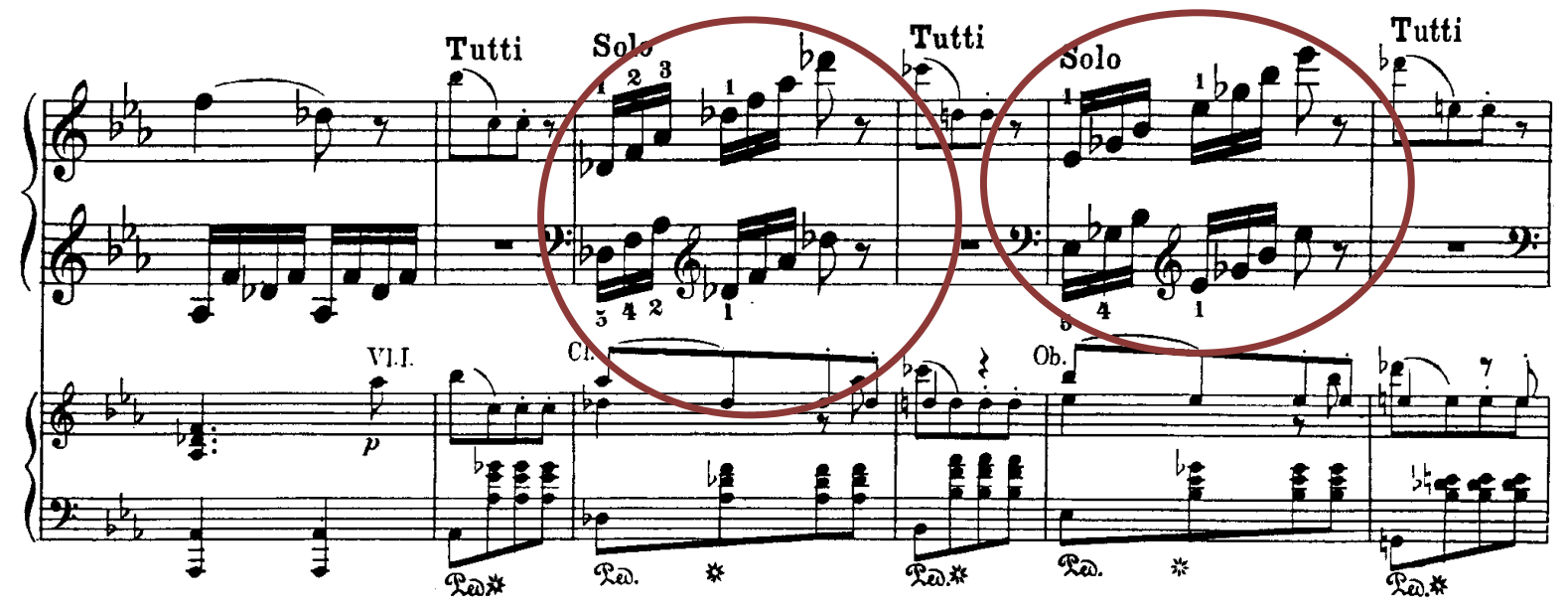

Figure 12: Op. 37 3. Piano Concerto $3^{\text {rd }}$ Movement $381-386^{\text {th }}$ Measures (Before Coda)

It is for sure that these patterns are not identical but the similarity in their structure and their closeness in terms of the ideas prove that they consist of the patterns used in the first movement.

Finally, octave descending at the end of the third movement consists of the theme before the representation of the first movement.

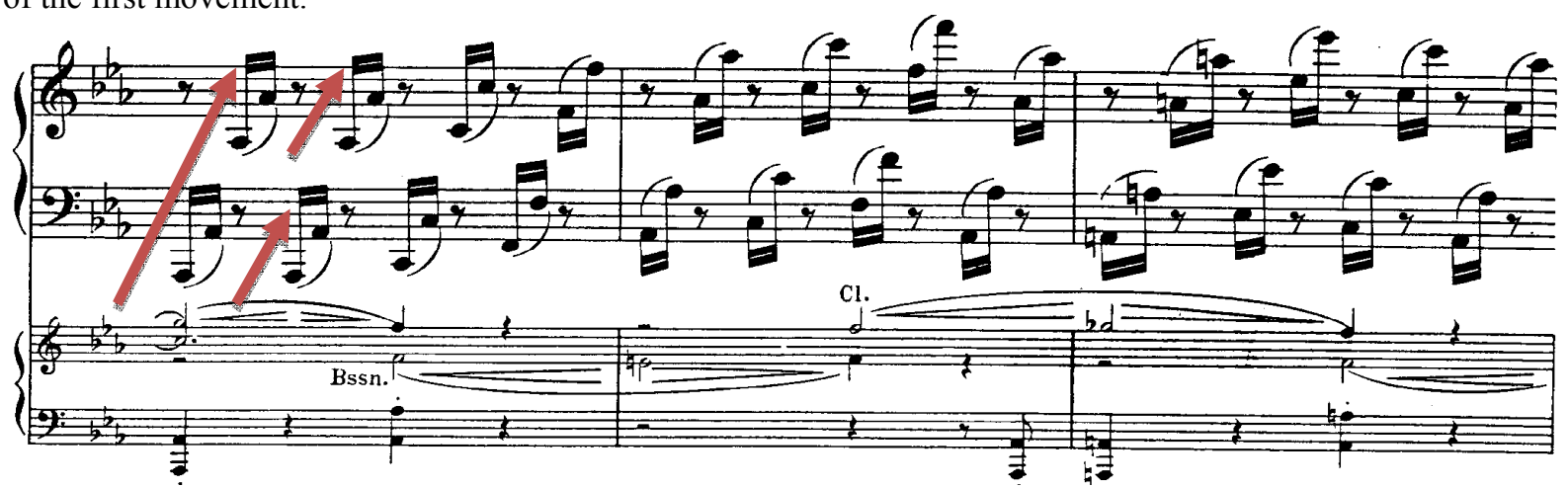

Figure 13: Op. 37 3. Piano Concerto 297-299 $9^{\text {th }}$ Measures (Before Representation) 


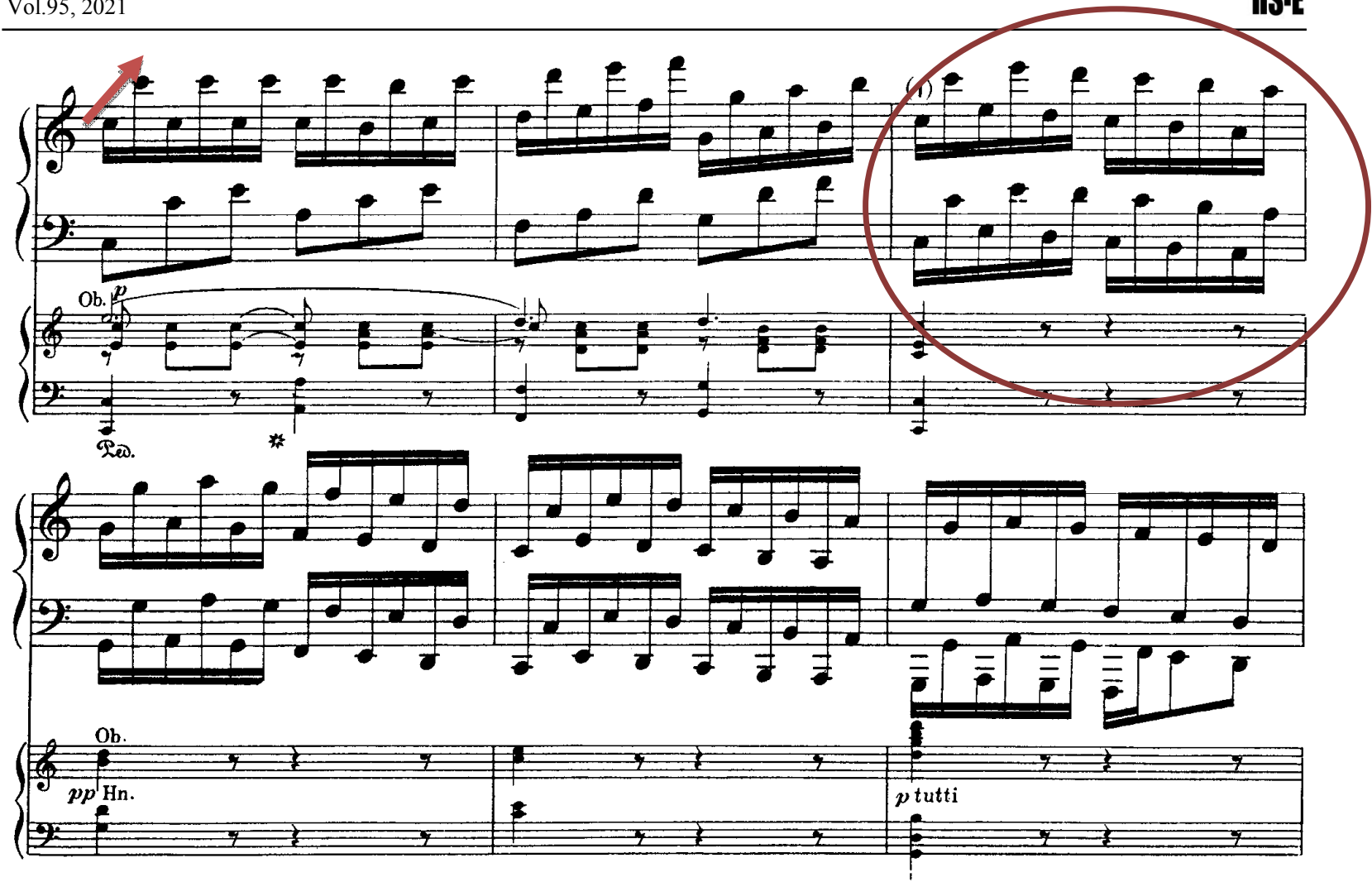

Figure 14: Op. 37 3. Piano Concerto $453^{\text {rd }}-458^{\text {th }}$ Measures (Closure)

The ascending octave movement in Figure 13 is seen in the last measures of the third movement. Especially the part of the octaves which was written for both hands in Figure 14, reminds the octave theme of the first movement. The difference here is that the octaves in the third movement were written in unison. In addition to the similarity in the ascending movement here, the closeness of both themes in terms of the ideas is remarkable.

In line with this analysis, A theme, developing movement and transition bridges among the themes in the first movement compose the A, B1, C and coda parts of the third movement. The mastership here is that the frame structure is almost the same whereas, themes do not resemble each other melodically.

\section{Conclusion}

In addition to this concerto, analytical perspective of Beethoven can be perceived in his other works such as piano sonatas and symphonies. Although this situation seems something to be simplified, it is actually the masterfully composition of numerous melodies that compose of a minimal thought. The composition tradition of his time supports his analytical approach. In other words, it is possible to see the traces of this approach in other composers when they are examined in detail. At this point, what distinguishes Beethoven from the others is that he did not prefer to make himself to be liked by the aristocracy. Instead, he chose to express his ideas through his music. This enabled seemingly minimal thoughts in his works to be created on deeper grounds.

From a performer point of view, it is thought that this information will be useful in the learning process. Even though the melodic structure of the themes emerging from the same structure are different from each other, to be able to understand the main structure will shorten the learning process of the work and ease the memorization. In line with all these, analyzing the work within this context enlightens not only this concerto but also works in late period of Beethoven.

\section{Referances}

Gerig, R. R. (2007), "Famous Pianists And Their Technique” Bloomington, IN, USA: Indiana University Press. Herriot, E. (2002), "Beethoven" (Çev: C. Aktüze) Istanbul: Pan Yayıncilık. Schindler, A. F. (1996), "Beethoven As I Knew Him” Mineola, NY, USA: Dover Publications, Inc.

Schonberg, H. c. (2013), "The Lives of the Great Composers"(Çev: A. F. Yıldırım) Istanbul: Doğan Egmont Yayıncılık ve Yapımcılık A. Ş. 